Александар Петровић

„Унион - Никола Тесла"

Факултет за менаџмент некретнина

Филип Петровић

Универзитет у Београду

Архитектонски факултет
005

https://doi.org/10.18485/filkult.2016.2.ch20

\title{
СТРУЧНА ТЕРМИНОЛОГИЈА У НАСТАВИ
}

\section{Сажетак}

Филологија је, по дефиницији, наука која се бави проучавањем језика и књижевност на том језику као и историјски и културолошки контекст који су неопходни за правилно разумевање књижевних дела и других културолошки значајних текстова на датом језику. Филологија подразумева проучавање граматике, реторике, историје као и интерпретацију аутора и традиција везаних за дати језик.

У наставној теорији и пракси, када је грађевинарство у питању, потребно је веома пажљиво (користећи све ,алате” којима филологија располаже) приближити ову мултидисциплинарну делатност како студентима тако и широј публици. Мултидисциплинарност ове гране привреде подразумева велику разноликост појмова и активности које треба путем едукативног процеса имплементирати тако да студенти буду оспособљени за перманентну, критичку и стваралачку примену стечених знања.

На тај начин, кроз функционалну писменост, оспособљавамо студенте за даље коришћење читања, писања и разумевања у оквиру сопственост и друштвеног знања.

С обзиром на грађевинарство, у оквиру своје делатности, ангажује 60 различитих врста привредних субјеката, од изузетне је важности правилна употреба језика како у изражавању тако и у писаном облику како знање и разумевање „руку под руку" допринело даљем развоју ове делатности у теорији и пракси.

Кључне речи: филологија, грађевинарство, мултидисциплинарност, знање, разумевање 
С обзиром да грађевинарство, у оквиру своје делатности, ангажује 60 различитих врста привредних субјеката, од изузетне је важности правилна употреба језика како у изражавању тако и у писаном облику како би знање и разумевање допринело даљем развоју ове делатности у теорији и пракси.

На почетку сваког сазнања треба одговорити на што више питања која почињу са: „ШТА JE?», како бисмо дефинисали основне појмове који су предмет нашег интересовања.

Из тог разлога дајемо дефиницију појма менаџмент као и свих осталих појмова дефинисаних у члану 2 Закона о планирању и изградњи:

MEHAЏMEHT - дефинише се као:

Посебна научна дисциплина, мултидисциплинарног карактера која се бави истраживањем проблема управљања пословима, подухватима и друштвеним системима.

Ова дисциплина проучава управљање као сложени процес ради што ефикаснијег постизања циља.

Састоји се од посебних процеса: планирања, организовања, вођства и контроле;

- Планирање је фаза менаџмент процеса у којој се доносе одлуке о мисији и циљевима организације и одређује курс акције неопходан за њихово остваривање, (у фази планирања јасно се могу препознати два садржаја који се односе на могућности пословног подухвата - предвиђање и спремност да се уђе у реализацију идеје о том пословном подухвату - одлучивање);

- Организовање је фаза менаџмент процеса у којој менаџери морају одредити ресурсе, дефинисати послове и конкретне задатке, извршити поделу рада, одредити активности и људе који су неопходни за остварење постављених циљева;

- Вођство је процес којим сеутиче на друге како би се ангажовали на најбољи начин ради ефикасног и ефективног коришћења организационих ресурса;

- Контрола је фаза менаџмент процеса која мора да омогући да се све планиране активности и резултати заиста и остваре; њена суштина се састоји у надгледању и уочавању карактеристика и ефеката предузетих активности. 
Основни појмови према Закону о планирању и изградњи: имају следеће значење:

- намена земљишта јесте начин коришћења земљишта одређен планским документом;

- претежна намена земљишта јесте начин коришћења земљишта за више различитих намена, од којих је једна преовлађујућа;

- површина јавне намене јесте простор одређен планским документом за уређење или изградњу објеката јавне намене или јавних површина за које је предвиђено утврђивање јавног интереса у складу са посебним законом (улице, тргови, паркови и др.);

- обухват плана јесте просторно или административно одређена целина за коју је предвиђена израда неког просторног или урбанистичког плана у складу са законом;

- урбана обнова јесте скуп планских, градитељских и других мера којима се обнавља, уређује или реконструише изграђени део града или градског насеља;

- регулациона линија јесте линија која раздваја површину одређене јавне намене од површина предвиђених за друге јавне и остале намене;

- грађевинска линија јесте линија на, изнад и испод површине земље и воде до које је дозвољено грађење основног габарита објекта;

- номенклатура статистичких територијалних јединица јесте скуп појмова, назива и симбола који описује групе територијалних јединица са нивоима груписања и која садржи критеријуме по којима је извршено груписање, а коју усваја Влада, на предлог републичког органа надлежног за послове статистике;

- бруто развијена грађевинска површина јесте збир површина свих наџемних етажа објекта, мерених у нивоу подова свих делова објекта - спољне мере ободних зидова (са облогама, парапетима и оградама);

- индекс заузетости парцеле јесте однос габарита хоризонталне пројекције изграђеног или планираног објекта и укупне површине грађевинске парцеле, изражен у процентима;

- индекс изграђености парцеле јесте однос (количник) бруто развијене грађевинске површине изграђеног или планираног објекта и укупне површине грађевинске парцеле; 
- ЕСПОН јесте европска мрежа институција које се баке прикупљањем информација и показатеља за просторно планирање;

- директива шспире је документ којим се постављају основна правила усмерена ка успостављању шфраструктуре просторних информација у Европској унији, а у Србији се спроводи кроз пационалну инфраструктуру геопросторних података;

- насељено место јесте изграђени, функционално обједињени простор на коме су обезбеђени услови за живот и рад људи и задовољавање заједничких потреба становника;

- I радјесте насеље које је као град утврђено законом;

- ссло јесте насеље чије се становништво претежно бави пољопривредом, а које није седнштс општине;

- грађевинско подручјејесте уређени и изграђени део насељеног места, као и неизграђени доо подручја одређен планским документом за заштиту, уређење или изградњу објекта;

- грађевинска парцела јесте део грађевинског земљишта, са приступом јавној саобраћајној понршини, која је изграђена или планом предвиђена за изградњу;

- грађевински комплекс представља целину која се састоји од више међусобно моиезаних самосталних функционалних целина, односно катастарских парцела, које могу нмати различиту намену;

- инвеститор јесте лице за чије потребе се гради објекат и на чије име гласи грађевинска дспвола;

- објекат јесте грађевина спојена са тлом, која представља физичку, функционалну, тсхничко-технолошкуилибиотехничкуцелину (зграде свихврста, саобраћајни, модопривредни и енергетски објекти, објекти инфраструктуре електронских комуникација -кабловска канализација, објекти комуналне инфраструктуре прикључак на електроенергетску мрежу, индустријски, пољопривредни и други привредни објекти, објекти спорта и рекреације, гробља, склоништа и сл.) који може бити поџемни или иаџемни;

- објекти јавне намене су објекти намењени за јавно коришћење и могу бити објекти јавне намене у јавној својини по основу посебних закона (линијски инфраструктурни објекти, објекти за потребе државних органа, органа територијалне аутономије и локалне самоуправе итд.) и остали објекти јавне намене који могу бити у 
свим облицима својине (болнице, домови здравља, домови за старе, објекти образовања, отворени и затворени спортски и рекреативни објекти, објекти културе, саобраћајни терминали, поште и други објекти);

- класа у смислу овог закона представља групу грађевинских објеката, односно радова, сврстаних према заједничким карактеристикама у погледу структурне и технолошке сложености, утицаја на животну средину и намене, односно ризика који прати њихово извођење односно коришћење;

- зградајесте објекат са кровом и спољним зидовима, изграђена као самостална употребна целина која пружа заштиту од временских и спољних утицаја, а намењена је за становање, обављање неке делатности или за смештај и чување животиња, робе, опреме за различите производне и услужне делатности и др. Зградама се сматрају и објекти који имају кров, али немају (све) зидове (нпр. надстрешница), као и објекти који су претежно или потпуно смештени испод површине земље (склоништа, поџемне гараже и сл.);

- помоћни објекат јесте објекат који је у функцији главног објекта, а гради се на истој парцели на којој је саграђен или може бити саграђен главни стамбени, пословни или објекат јавне намене (гараже, оставе, септичке јаме, бунари, цистерне за воду и сл.);

- економски објекти јесу објекти за гајење животиња (стаје за гајење коња, штале за гајење говеда, објекти за гајење живине, коза, оваца и свиња, као и објекти за гајење голубова, кунића, украсне живине и птица); пратећи објекти за гајење домаћих животиња (испусти за стоку, бетонске писте за одлагање чврстог стајњака, објекти за складиштење осоке); објекти за складиштење сточне хране (сеници, магацини за складиштење концентроване сточне хране, бетониране сило јаме и сило тренчеви), објекти за складиштење пољопривредних производа (амбари, кошеви) и други слични објекти на пољопривредном газдипству (објекти за машине и возила, пушнице, сушионице и сл.);

- линијски инфраструктурни објекат јесте јавни пут, јавна железничка инфраструктура, електроенергетски вод, нафтовод, продуктовод, гасовод, објекат висинског превоза, линијска инфраструктура електронских комуникација водоводна $и$ канализациона инфраструктура и сл. који може бити наџемни или 
поџемни, чија изградња је предвиђена одговарајућим планским документом;

- тунели (путни, железнички или за посебну намену) су посебна врста поџемних инфраструктурних објеката, чијом изградњом се не нарушава коришћење земљишта на површини терена постојеће намене, уз евентуална техничка ограничења које дефинише плански документ;

- комунална инфраструктура јесу сви објекти инфраструктуре за које решење за извођење радова, односно грађевинску дозволу издаје јединица локалне самоуправе;

- клизиште је вид ерозије земљишта која се одвија под утицајем природних и сеизмолошких прилика при чему се део стеновите или растресите масе одваја од подлоге и неконтролисано клизи по клизној површини;

- припремни радови јесу радови који претходе грађењу објекта и односе се нарочито на: рушење постојећих објеката на парцели, измештање постојеће инфраструктуре на парцели, рашчишћавање терена на парцели, обезбеђење простора за допрему и смештај грађевинског материјала и опреме, грађење и постављање објеката, инсталација и опреме привременог карактера за потребе извођења радова (постављање градилишне ограде, контејнера и сл.), земљани радови, радови којима се обезбеђује сигурност суседних објеката, односно сигурност и стабилност терена (шипови, дијафрагме, потпорни зидови и сл.), обезбеђивање несметаног одвијања саобраћаја и коришћење околног простора;

- техничка документација јесте скуп пројеката који се израђују ради: утврђивања концепта објекта, разраде услова, начина изградње објекта и за потребе одржавања објекта;

- изградња објекта јесте скуп радњи који обухвата: претходне радове, израду и контролу техничке документације, припремне радове за грађење, грађење објекта и стручни наџор у току грађења објекта;

- грађење јесте извођење грађевинских и грађевинско-занатских радова, уградња инсталација, постројења и опреме;

- реконструкција јесте извођење грађевинских радова на постојећем објекту у габариту и волумену објекта, којима се: утиче 
на стабилност и сигурност објекта и заштиту од пожара; мењају конструктивни елементи или технолошки процес; мења спољни изглед објекта или број функционалних јединица врши замена уређаја, постројења, опреме и 1ПК штшија са повећањем капацитета;

- рсконструкција линијског инфраструктурног објекта јесте извођење грађевинских (НШрна у заштитном појасу, у складу са посебним законом, којима се може променити ГНбирит, волумен, положај или опрема постојећег објекта;

- радња јесте извођење грађевинских и других радова којима се изграђује нови мроетор ван постојећег габарита објекта, као и наџиђивање објекта, и са њим чини грпђсвинску, функционалну или техничку целину;

- адаптација јесте извођење грађевинских и других радова на постојећем објекту, којима еи; врши промена организације простора у објекту, врши замена уређаја, постројења, онрсме и инсталација истог капацитета, а којима се не утиче на стабилност и сигурност објскта, не мењају конструктивни елементи, не мења спољни изглед и не утиче на бсзбедност суседних објеката, саобраћаја, заштите од пожара и животне средине;

- санација јесте извођење грађевинских и других радова на постојећем објекту којима се врши поправка уређаја, постројења и опреме, односно замена конструктивних елемената објекта, којима се не мења спољни изглед, не утиче на безбедност суседних објеката, саобраћаја и животне средине и не утиче на заштиту природног и непокретног културног добра, односно његове заштићене околине, осим рестаураторских, конзерваторских и радова на ревитализацији;

- санација клизишта обухвата све радове којима се врши санирање клизишта насталих на грађевинском, шумском, пољопривредном, путном или другој врсти земљишта. Ови радови обухватају рашчишћавање и отклањање наноса насталих као последица клизања тла, пројектовање, обезбеђење потребне техничке документације, потребних грађевинских услова и извођење грађевинских радова потребних за санацију и заштиту од појаве новог клизишта;

- инвестиционо одржавање је извођење грађевинско-занатских, односно других радова зависно од врсте објекта у циљу побољшања услова коришћења објекта у току експлоатације; 
- текуће (редовно) одржавање објекта јесте извођење радова који се предузимају ради спречавања оштећења која настају употребом објекта или ради отклањања тих оштећења, а састоје се од прегледа, поправки и предузимања превентивних и заштитних мера, односно сви радови којима се обезбеђује одржавање објекта на задовољавајућем нивоу употребљивости, а радови на текућем одржавању стана јесу кречење, фарбање, замена облога, замена санитарија, радијатора и други слични радови;

- рестаураторски, конзерваторски и радови на ревитализацији културних добара су радови који се изводе на непокретним културним добрима и њиховој заштићеној околини, у складу са посебним и овим законом;

- градилиште јесте земљиште или објекат, посебно обележено, на коме се гради, реконструише или уклања објекат, односно изводе радови на одржавању објекта;

- уклањање објекта или његовог дела јесте извођење радова на рушењу објекта или дела објекта;

- стандарди приступачности јесу обавезне техничке мере, стандарди и услови пројектовања, планирања и изградње којима се осигурава несметано кретање и приступ особама са инвалидитетом, деци и старим особама;

- сепарат о техничким условима изградње (у даљем тексту: сепарат) јесте документ који доноси ималац јавних овлашћења у оквиру своје надлежности кад плански документ не садржи услове, односно податке за израду техничке документације, који садржи одговарајуће услове и податке за израду техничке документације, а нарочито капацитете и место прикључења на комуналну и другу инфраструктуру према класама објеката и деловима подручја за које се доноси;

- имаоци јавних овлашћења су државни органи, органи аутономне покрајине и локалне самоуправе, посебне организације и друга лица која врше јавна овлашћења у складу са законом;

- финансијер јесте лице које по основу закљученог и овереног уговора са инвеститором финансира, односно суфинансира изградњу, доградњу, реконструкцију, адаптацију, санацију или извођење других грађевинских односно инвестиционих радова предвиђених овим 
законом и на основу тог уговора стиче одређена права и обавезе које су овим законом прописане за инвеститора у складу са тим уговором, осим стицања права својине на објекту који је предмет изградње.

Како би се основни појмови према закону о планирању и изградњи имплементирали у пракси, законодавац је донео правилник о спровођењу оједињне процедуре електронским путем ради ефикаснијег добијања грађевинских и уптребних дозвола код изградње објекта.

У том смислу дајемо значење појединих израза употребљених у овом правилнику.

- надлежни орган јесте Министарство надлежно за послове грађевинарства (у даљем тексту: Министарство), орган аутономне покрајине надлежан за послове грађевинарства, односно надлежни орган јединице локалне самоуправе, у оквиру утврђених надлежности за издавање локацијских услова, односно грађевинске и употребне дозволе;

- надлежна служба јесте посебна организациона целина, у саставу надлежног органа (одсек, служба, одељење, управа и сл.), преко које надлежни орган спроводи обједињену процедуру;

-руководилац надлежне службе јесте лице које надлежни орган именује, односно распореди нарадно место руководиоца надлежне службе и које је одговорно за ефикасно спровођење обједињене процедуре;

- обједињена процедура јесте скуп поступака и активности које спроводи надлежни орган у вези са изградњом, доградњом или реконструкцијом објеката, односно извођењем радова, а који укључују издавање локацијских услова, издавање грађевинске дозволе, односно решења из члана 145. Закона о планирању и изградњи (у даљем тексту: Закон), пријаву радова, пријаву завршетка израде темеља и завршетка објекта у конструктивном смислу, издавање употребне дозволе, обезбеђење прикључења на инфраструктурну мрежу, упис права својине на изграђеном објекту и измену аката који се прибављају у овој процедури, као и прибављање услова за пројектовање, односно прикључење објекатана инфраструктурну мрежу, прибављање сагласности натехничку документацијуи прибављање исправа и других докумената које издају имаоци јавних 
овлашћења, а услов су за изградњу објеката, односно за издавање локацијских услова, грађевинске и употребне дозволе из њихове надлежности;

- Регистар обједињених процедура (у даљем тексту: Регистар) јесте електронска база података коју води надлежни орган кроз Централни информациони систем (у даљем тексту: ЦИС), у којој су садржани подаци о току сваког појединачног предмета, акта која је надлежни орган издао у обједињеној процедури, као и документација приложена или прибављена у поступку обједињене процедуре, а која је јавно доступна у складу са законом и овим правилником;

- ЦИС је информациони систем кроз који се спроводи обједињена процедура.

- Централна евиденција обједињених процедура (у даљем тексту: Централна евиденција) јесте јединствена, централна, јавна, електронска база података која се води у оквиру

Агенције за привредне регистре, у којој су обједињени подаци, акта и документацијасвих регистара обједињених процедура на територији Републике Србије, а којаје јавно доступна у складу са законом и овим правилником;

- регистратор регистра обједињених процедура (у даљем тексту: Регистратор) јесте лице које је одређено да води регистар обједињених процедура, односно руководилац надлежне службе ако у надлежном органу није одређен Регистратор;

- регистратор централне евиденције обједињених процедура (у даљем тексту: Регистратор централне евиденције) јесте лице које води Централну евиденцију и које је именовано у складу са Законом; -захтев јесте акт којим се покреће обједињена процедура, односно поједине фазе те процедуре;

- подносилац захтева јесте лице по чијем се захтеву покреће поступак обједињене процедуре, односно поједине фазе те процедуре.

Значење речи и израза чије смо дефиниције навели су само иницијални импулс за разумевање процеса који се одвијају у грађевинарству. Тек кроз примену разноврсних процеса то јест њихову инплементацију кроз употребу науке у менаџменту студенти ће моћи да буду оспособљени за даље читање писање и разумевање у оквиру сопственог и друштвеног знања. На тај начин ће бити спремни за перманентну, критичку и стваралачку примену стечених знања. 
Aleksandar Petrović

Faculty of Real Estate Management

University ,, Union- Nikola Tesla”

Filip Petrović

University of Belgrade

Faculty of Architecture

\section{PROFESSIONAL TERMINOLOGY IN TEACHING}

\section{Summary}

Philology is, by definition, the science that deals with the study of language and literature in that language as well as the historical and cultural context that are necessary for a proper understanding of literary works and other culturally significant texts in a given language. Philology involves the study of grammar, rhetoric, history and interpretation of the author and traditions related to the given language.

In teaching the theory and practice when it comes to construction equipment, it is necessary to very carefully (using all the tools ", "which has Philology) close this multidisciplinary activity both students and the general public. Multidisciplinary nature of this industry means a great variety of concepts and activities to be implemented through the educational process so that students are trained for a permanent, critical and creative application of acquired knowledge.

In this way, through functional literacy, we empower students to continue to use reading, writing and understanding in the framework of their own and social skills.

With regard to the construction industry, which in its activity, engage 60 different types of businesses, it is of utmost importance the proper use of language, as in the expression, and in writing how knowledge and understanding ,, hand in hand " contribute to the further development of this activities in theory and practice.

Key words: philology, construction, multidisciplinarity, knowledge, understanding 